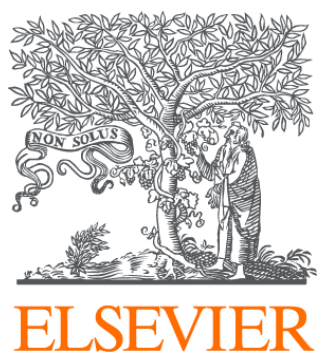

Since January 2020 Elsevier has created a COVID-19 resource centre with free information in English and Mandarin on the novel coronavirus COVID-

19. The COVID-19 resource centre is hosted on Elsevier Connect, the company's public news and information website.

Elsevier hereby grants permission to make all its COVID-19-related research that is available on the COVID-19 resource centre - including this research content - immediately available in PubMed Central and other publicly funded repositories, such as the WHO COVID database with rights for unrestricted research re-use and analyses in any form or by any means with acknowledgement of the original source. These permissions are granted for free by Elsevier for as long as the COVID-19 resource centre remains active. 


\section{Index to Volume 9, 2007}

\section{Author Index}

Adamama-Moraitou, K. K. 23

Aminlari, M. 133

Arai, T. 232

Archer, J. 72

Argyle, D. J. 72

Arispici, M. 242

Arjona, A. 14

Ataseven, V. S. 369

Atwell, R. B. 487

Baez, J. L. 411, 526

Baral, R. M. 67, 300

Barfield, D. M. 265

Barquero, N. 14

Barr, F. J. 424

Barrs, V. 521

Barrs, V. R. 346

Bates, N. 335

Battilani, M. 271

Baumann, A. 518

Beatty, J. A. 346

Belchior, C. 481

Bell, E. T. 300

Bendas, A. 309

Bertolini, G. 254

Bertoni, G. 387

Biondo, A. W. 518

Blot, S. 340

Blunden, A. S. 82

Bommer, N. X. 364

Bonazzi, M. 387

Boschiroli, M. L. 238

Bosward, K. L. 67

Bottarelli, E. 387

Boudet, K. G. 89, 382

Brearley, M. 72

Brewer, M. 196

Brunt, J. 466

Buracco, P. 140

Burrow, R. 373

Butt, J. A. 289
Caccamo, R. 140

Cairns, K. 196

Campbell, A. 335

Can-Şahna, K. 369

Cantile, C. 242

Cappello, R. 109

Carrera-Martín, F. 188

Catt, M. J. 67

Celimli, N. 499

Chen, S. C. A. 67

Cherubini, G. B. 109, 246

Clarke, H. E. 97

Collado, V. M. 14

Colon, J. A. 494

Corgozinho, K. B. 481

Corston, C. 364

Cottam, N. 44

Courtin, F. 238

Cripps, P. 373

da Silva, M. A. 481

Damico, C. B. 481

Dawson, S. 373

Day, M. J. 72

de Arespacochaga, A. G. 226

De La Farge, F. 89

De Man, M. M. G. 432

de Morais, H. A. 518

de Souza, H. J. M. 481

De Stefani, A. 157

Dean, R. 359

Delisle, F. 340

Dennis, R. 157

Dennler, R. 168

Dhaliwal, R. S. 61

Dixon, M. J. 313

Dodman, N. H. 44

Doménech, A. 14

Downing, R. 466

Duarte, R. 309

Ducatelle, R. V. 432
Dumas, P. 238

Dye, C. 202

Ebisawa, T. 29

Egan, K. 8

Egberink, H. F. 439

Eggertsdóttir, A. V. 458

Ekici, H. 435

Enomoto, Y. 29

Erb, H. N. 124

Esfandiari, A. 133

Esmaelli, H. 514

Fascetti, A. J. 97

Faucher, M. R. 382

Firat, I. 435

Forterre, F. 36

Foster, S. F. 161, 172

Fujita, M. 232

Fyfe, J. 238

Gajanayake, I. 56

García-Belenguer, S. 188

Gaskell, C. J. 373

Gaskell, R. M. 373

Gazzola, M. 387

Geffre, A. 382

Gelain, M. E. 271

Germain, C. 382

Giordano, A. 271

Glaus, T. M. 168

Glickman, L. T. 351

Glickman, N. W. 351

Gnirs, K. 340

Gnudi, G. 387

Goldstein, R. E. 124

Gomes, L. A. M. 309

Gomez-Lucia, E. 14

Gouletsou, P. G. 23

Granger, N. 340

Greene, C. E. 439 
Greiner, M. 404

Griessmayr, P. 439

Gruffydd-Jones, T. J. 8

Guenther-Yenke, C. L. 451

Guimarães, A. M. S. 518

Gunn-Moore, D. 278

Gunn-Moore, D. A. 214, 289, 364

Guptill, L. 351

Hagedorn, J. E. 466

Haktanir-Yatkin, D. 435

Hales, L. 300

Hart, C. A. 373

Hartley, C. 78

Hartmann, K. 404, 439

Harvey, A. M. 424

Hasegawa, D. 232

Haugland, S. 72

Hauser, B. 168

Hawley, J. R. 258

Hayashi, D. 232

Healey, K. A. E. 373

Hellyer, P. 466

Helps, C. R. 8

Herrtage, M. E. 72

Hidalgo, A. 340

Hittmair, K. M. 226

Holloway, A. 72

Holt, P. E. 424

Hori, Y. 29

Howard, J. 36

Huerre, M. 238

Innocenti, C. M. 219

Isaia, M. C. 392

Ishak, A. M. 1

Ishikawa, Y. 29

Jaggy, A. 36

Jarrett, O. 8, 439

Kagi, A. 503

Kass, P. H. 97

Khoo, A. M. L. 346

Khoshnegah, J. 514

Kirpensteijn, J. 397

Kobayashi, M. 232

Konar, M. 36

Koyama, H. 503

Kramer, M. 509

Krockenberger, M. 446

Krontveit, R. 458

Kudnig, S. T. 219
Kufuor-Mensah, E. 61

Kumru, I. H. 499

Labarthe, N. 309

Ladlow, J. 78

Lamb, C. R. 109

Langley-Hobbs, S. J. 177

Lappin, M. R. 1, 97, 196, 219, 258

Laroute, V. 89

Le Garreres, A. 89

Lefebvre, H. P. 89, 382

Lenard, Z. M. 161

León-Artozqui, M. 188

Leperlier, D. 340

Lester, N. V. 161

Lieskovsky, J. 117

Lingard, A. 521

Litster, A. L. 487

Lossi, L. 242

Lund, H. S. 458

MacPhail, C. M. 219

Maddern, K. 521

Maede, Y. 232

Maggs, D. J. 97

Mahoney, P. 246

Maiorka, P. C. 51

Malik, R. 67, 265, 300, 418, 446, 521

Mannelli, A. 392

Marchevsky, A. M. 346

Maritato, K. C. 494

Martín, D. 14

Martin, P. 67, 418, 446

Martins, M. C. L. 481

Mauterer, J. V. 494

Mayer-Roenne, B. 124

McCann, T. M. 214, 289, 364

McConnell, J. F. 82

McKiernan, B. C. 140

McNeil, P. E. 72

Mellor, P. J. 72

Menzano, A. 392

Messick, J. B. 518

Metzger, C. 271

Michel, K. E. 411, 526

Morato, G. S. 51

Muir, W. W. 150

Nakamura, S. 232

Nassiri, S. M. 514

Neath, P. J. 82

Negrin, A. 109

Norris, J. M. 300
O'Brien, C. 446

Oğuzoğlu, T. Ç. 369

O'Hara, A. J. 161

Orima, H. 232

Ossent, P. 168

Palacio, J. 188

Paltrinieri, S. 271

Pastor-Villalba, E. 188

Pegrum, S. A. 265

Pereira, A. N. 481

Pereira, Y. M. 364

Pınar, D. 369

Pinchbeck, G. L. 373

Pinches, M. D. G. 8

Platt, S. 157

Pocacqua, V. 271

Polton, G. A. 72

Powell, R. M. 72

Prahl, A. 351

Prassinos, N. N. 23

Radecki, S. 1

Radford, A. D. 373

Rallis, T. S. 23

Rambozzi, L. 392

Reed, N. 214, 278, 364

Reynolds, B. S. 382

Righi, D. A. 51

Rizzo, F. 319, 424

Robertson, S. A. 313, 466

Rodan, I. 466

Rogers, Q. R. 97

Rollin, B. E. 326

Romano, S. 392

Rossetti, E. 254

Rozanski, E. A. 451

Rusbridge, C. 246

Russell, N. J. 161

Salvadori, C. 242

Sansom, J. 82

Satoh, H. 232

Scase, T. J. 72

Schachenmayr, W. 509

Schmidt, M. J. 509

Schoeniger, S. 246

Schull, D. N. 487

Schulz, B. 439

Serrão, M. L. 309

Seyrek-Intas, D. 499

Seyrek-Intas, K. 499

Shahbazkia, H. R. 133 
Shales, C. J. 177

Sharifi, H. 514

Shaw, D. J. 289

Shaw, S. E. 258

Shibly, S. 226

Shoda, T. 232

Shofer, F. S. 411, 526

Siddell, S. G. 202

Simpson, K. 263, 278

Simpson, K. E. 214, 289, 364

Singh, B. P. 246

Sissener, T. R. 177

Smith, K. C. 72, 78

Smith, S. H. 56

Snow, D. 265

Sontas, B. H. 435

Soon, L. 67

Sorenmo, K. 411, 526

Sørum, H. 458

Sparkes, A. H. 82

Spergser, J. 226

Spinosa, H. S. 51

Sutton, N. M. 335

Sykes, J. E. 97

Tagawa, M. 503

Takahashi, K. 232
Tappin, S. 359

Tappin, S. W. 319

Tasker, S. 8, 319, 424

Taylor, P. M. 313

Tebb, A. J. 161

Tejerizo, G. 14

Tennant, B. 214

Tetrick, M. 351

Thibaud, J.-L. 340

Thiel, C. 509

Ticehurst, K. 521

Tisdall, P. L. C. 418

Tomek, A. 36

Toribio, J.-A. L. M. L. 300

Toural, C. 14

Tsuchida, S. 503

Tuna, B. 499

Twedt, D. C. 140

Uechi, M. 29

Ugai, J. 29

van Nimwegen, S. A. 397

Vandevelde, M. 36

Veir, J. K. 219

Vidotto, O. 518
Vidyashankar, A. N. 439

Villiers, E. J. 72

Volta, A. 387

Voss, K. 117

Waldron, M. K. 97

White, J. D. 300

Wieczorek, L. 157

Wiese, A. J. 150

Wigney, D. I. 300

Wolf, G. 404

Wray, J. D. 56

Xavier, F. G. 51

Yamano, S. 29

Yamasaki, M. 232

Yamato, O. 232

Yoo, S. H. 97

Zaki, S. 521

Zeugswetter, F. 226

Zini, E. 168

Zotti, A. 254 


\section{Subject Index}

AAHA/AAFP pain management guidelines for dogs and cats 466

A case of feline leprosy caused by Mycobacterium lepraemurium originating from the island of Kythira (Greece): diagnosis and treatment 238

Acute non-ambulatory tetraparesis attributable to cranial cervical intervertebral disc disease in a cat 494

Anaesthetic and cardiopulmonary effects of intramuscular morphine, medetomidine and ketamine administered to telemetered cats 150

A prospective investigation of the prevalence and prognostic significance of weight loss and changes in body condition in feline cancer patients 411

Attraction of mosquitoes to domestic cats in a heartworm enzootic region 309

Atypical manifestations of feline inflammatory polyps in three cats 219

Bacteraemia in 66 cats and antimicrobial susceptibility of the isolates (1995-2004) 404

Bacteriuria in cats with feline lower urinary tract disease: a clinical study of 134 cases in Norway 458

Bilateral subcutaneous fibrosarcomas in a cat following feline parvo-, herpes- and calicivirus vaccination 432

Catheter-induced urethral trauma in cats with urethral obstruction 481

Choanal atresia in a Himalayan cat - first reported case and successful treatment 346

Clinical and molecular analysis of GM2 gangliosidosis in two apparent littermate kittens of the Japanese domestic cat 232

Clinical effects and outcome of feline permethrin spot-on poisonings reported to the Veterinary Poisons Information Service (VPIS), London 335

Cobalamin, folate and inorganic phosphate abnormalities in ill cats 278

Co-infection with Mycoplasma haemofelis and 'Candidatus Mycoplasma haemominutum' in three cats from Brazil 518

Comparison of a new device for blood sampling in cats with a vacuum tube collection system plasma biochemistry, haematology and practical usage assessment 382

Congestive heart failure associated with a large transverse left ventricular moderator band in a cat 56

Corrigendum to "A prospective investigation of the prevalence and prognostic significance of weight loss and changes in body condition in feline cancer patients" [Journal of Feline Medicine and Surgery 9 (2007) 411-417] 526

Cryptic disease in a cat with painful and swollen hocks: an exercise in diagnostic reasoning and clinical decision-making 418

Cutaneous haemangiosarcoma of the lower eyelid in an elderly white cat 78

Cystic liver disease related to high Platynosomum fastosum infection in a domestic cat 51

Diagnosis of feline leukaemia virus infection by semi-quantitative real-time polymerase chain reaction 8

Disposition of plasma creatinine in non-azotaemic and moderately azotaemic cats 89

Distribution of arginase in tissues of cat (Felis catus) 133

Dr James Robert Richards Jr; July 19, 1948-April 24, 2007263

Dr Jean Holzworth, Pioneer in feline medicine 264

ECG of the month: bradyarrhythmia in an anaesthetised, elderly, hypertensive cat 521

Effect of an odor eliminator on feline litter box behavior 44

Effects of dietary lysine supplementation in cats with enzootic upper respiratory disease 97

Effects of enalapril in cats with pressure overloadinduced left ventricular hypertrophy 29

Endoscopic bronchial anatomy in the cat 140

Eosinophilic fibrosing gastritis and toxoplasmosis in a cat 82

Eosinophilic leukaemia in a cat 514

Erosive polyarthritis associated with Mycoplasma gateae in a cat 226

Ethical issues in geriatric feline medicine 326

Evaluation of a novel nested PCR for the routine diagnosis of feline leukemia virus (FeLV) and feline immunodeficiency virus (FIV) 14

Evaluation of the use of thermal thresholds to investigate NSAID analgesia in a model of inflammatory pain in cats 313

Feline diabetes mellitus in the UK: the prevalence within an insured cat population and a questionnaire-based putative risk factor analysis 289

Genomic RNA sequence of feline coronavirus strain FCoV C1Je 202

Incidence of and risk factors for cat bites: a first step in prevention and treatment of feline aggression 188 
Laparoscopic ovariectomy in cats: comparison of laser and bipolar electrocoagulation 397

Lymphangiosarcoma in two cats 161

Metastatic squamous cell carcinoma in a cat 61

Multiple meningiomas: clinical, radiological, surgical, and pathological findings with outcome in four cats 36

Multilobular tumour of bone of the thoracic wall in a cat 254

Pansteatitis and severe hypocalcaemia in a cat 168

Prevalence of Coxiella burnetii DNA in vaginal and uterine samples from healthy cats of northcentral Colorado 196

Prevalence of cryptosporidian infection in cats in Turin and analysis of risk factors 392

Prevalence of feline chronic gingivo-stomatitis in first opinion veterinary practice 373

Prevalence of feline immunodeficiency virus infection in domesticated and feral cats in eastern Australia 300

Prevalence of Mycoplasma haemofelis, 'Candidatus Mycoplasma haemominutum', Bartonella species, Ehrlichia species, and Anaplasma phagocytophilum DNA in the blood of cats with anemia 1

Prevalence of Rickettsia felis DNA in the blood of cats and their fleas in the United States 258

Prevalence of the polycystic kidney disease and renal and urinary bladder ultrasonographic abnormalities in Persian and Exotic Shorthair cats in Italy 387

Prevalence of Tritrichomonas foetus infection in cats with diarrhoea in the UK 214

Pupillary dilation, tachycardia and abnormal behaviour in a young cat 265

Quality of different in-clinic test systems for feline immunodeficiency virus and feline leukaemia virus infection 439

Recurrent spinal arachnoid cyst in a cat 509

Results of magnetic resonance imaging in 14 cats with meningoencephalitis 109

Retrospective analysis of selected predictors of mortality within a veterinary intensive care unit 364

Rostral cerebellar arterial infarct in two cats 246

Serum $\alpha 1$-acid glycoprotein (AGP) concentration in non-symptomatic cats with feline coronavirus (FCoV) infection 271
Severe abdominal dog bite wounds in a pregnant cat 499

Solitary plasmacytoma of bone in two successfully treated cats 72

Spinal cord injury resulting from incorrect microchip placement in a cat 157

Spongiform neurodegenerative disease in a Persian kitten 242

Successful treatment of a localised CDC Group EF-4a infection in a cat 67

Successful treatment of cervical spinal epidural empyema secondary to grass awn migration in a cat 340

Symphyseal distraction-osteotomy using a novel spacer of spirally fashioned orthopaedic wire for the management of obstipation 23

Tension band stabilisation of acetabular physeal fractures in four kittens 177

The detection of feline coronaviruses in blood samples from cats by mRNA RT-PCR 369

Thrombocytosis in cats: a retrospective study of 51 cases (2000-2005) 319

Tick toxicity in cats caused by Ixodes species in Australia: a review of published literature 487

Time trends and risk factors for diabetes mellitus in cats presented to veterinary teaching hospitals 351

Tracheostomy in cats: 23 cases (1998-2006) 451

Trauma-induced growth abnormalities of the distal radius in three cats 117

Treatment and long-term follow-up of extrahepatic biliary obstruction with bilirubin cholelithiasis in a Somali cat with pyruvate kinase deficiency 424

Urinary tract infections in cats with hyperthyroidism, diabetes mellitus and chronic kidney disease 124

Vulvar leiomyosarcoma in a cat 435

What is Your Diagnosis? Progressive abdominal distention 359

What is Your Diagnosis? Chronic progressive stertor in an 11-year-old cat 446

Xanthine urolithiasis in a cat: a case report and evaluation of a candidate gene for xanthine dehydrogenase 503 